\title{
Governance of Money Laundering: An Application of the Principal-agent Model
}

\author{
Syed AZHar Hussain Shah, Syed AKhter Hussain Shah, and Sajawal Khan
}

\section{INTRODUCTION}

Money laundering has an element of a bate for one individual and a tool of exploitation for another individual and carries an externality (positive or negative) for the society. Its multifarious nature is analysed in perspective of Principal-Agent-Client Model of Provan and Milward (2001). Model of Network Evaluation by Provan and Milward (2001) is originally used for health and social sector; however this model is extended and applied for governance of money laundering. In this model we evaluate the affectivity of the network of money transaction with the objective function to minimise transaction of money through money laundering by making laws and procedure and get these implemented through agents. As there is involvement of multiple stakeholders, therefore, evaluation of network effectiveness is made at three levels i.e. at community level to analyse: community, the network itself and the network's organisational participants. These levels are of interest to three major constituents of money transaction network such as principal, agent, and clients.

Highlighting the significance of involvement and interests of stakeholders in the network Provan and Milward (1983) insists that a network must satisfy the needs and expectations of those groups within a community that are both a direct and indirect interest in seeing that client needs are adequately met. This would enable us to visualise whether the structure of existing network and strategies of principal and agents are optimal and sustainable to achieve their short run and long run objectives? The strategies of clients and agents are also analysed in view of their payoffs i.e. present value of cost and returns by adopting a specific strategy out of available options and choices. The present value of cost and returns are calculated along the lines of Becker (1975 and 1993) Model of investment in human capital. For elaborate analysis the paper is accordingly organised.

Section two deals with stake holders of principal agent model and, basic concepts and information regarding money laundering. Section three highlights negative externalities of money laundering. Losses to the principal are discussed in Section four.

Syed Azhar Hussain Shah is associated with St. George College, London, U.K. Syed Akhtar Hussain Shah and Sajawal Khan are PhD student at the Pakistan Institute of Development Economics, Islamabad.

Authors' Note: This paper draws on a chapter of Syed Azhar Hussain Shah PhD thesis. The authors are grateful to Dr Rashid Aziz and Dr Noreen Talha for their comments, and to Dr Nadeem Ul Haque for encouragement to wrote it. They also acknowledge comments of Dr Eatzaz Ahmed, Dr Syed Nisar Hussain Hamdani, and Dr Rehana Siddiqui. 
Strategy of the principal and money laundering counter-measures are discussed in Section five and six. Similarly Section seven highlights role of the Bretton Woods Institutions. Section eight presents proposed model. Conclusion and recommendation are given in Sections nine and ten respectively.

\section{MONEY LAUNDERING: AN OVERVIEW}

An over view of money laundering is given for understanding of this mean of money transaction. A brief description of stake holders of money laundering, nature of money laundering its components, its characteristics and methods of money laundering are presented.

\subsection{Stakeholders of the Principal-Agent Model}

The system of monetary transaction involves a number of stake holders such as the service providers, service demanding individuals and the regulator. Similarly, in purely principal-agent model perspective these stakeholders are named as principal, agent, and clients. These actors involved in the model are described below.

Principal: in this model of money laundering is International Financial regime who governs money transaction directly through different channels by making laws to regulate this process. Different laws, rules and procedures are made to make money transaction more transparent and monitorable and take measures to control money laundering. International Financial regime comprises two types of organisations; one type of organisations is established to perform multiple functions which also include antimoney laundering for example United Nations, World Bank, International Monetary Funds. The other type of organisations and institutions are developed to achieve specific objectives of anti-money laundering such as Financial Action Task Force (FATF), FATF Style Regional Bodies (FSRBs), Egmont Group and Wolfsberg Group of banks etc.

The principal utilises the services of agents to perform its function of anti-money laundering at state level and international level. Agents are mainly categorised into two groups.

Formal Agents include the states, banking and financial institutions and organisations being operationalised in governance of money transactions through different channels.

Informal Agents belong to non regulated or partially regulated sector. Their activities are not fully monitored and tracked by the regulator for example money changer and underground elements involved in money transaction.

A part of money transaction also takes place through money laundering. The agents may be instrumental or otherwise in the measures to be carried out to curb money laundering. The services of agents are utilised by clients to facilitate both legitimate and illegitimate transaction of money.

Clients: are the individuals, group or organisation who get services of any type of agent for transactions of their money through different means at international and local levels.

All the integrating partners of the financial system that is principal, agent and client, make their decisions rationally while taking into account the available choices and their preferences. They count present value of their costs of making specific decisions 
regarding their role in system of money transaction and present value of returns from adopting specific role.

\subsection{Money Laundering: Its Nature and Scope}

In simple words the money laundering is defined as process of "turning of dirty money into clean money". Money laundering is like washing and cleaning of dirty clothes. Crucial element in the process of laundering is the act of concealment and cycling. So in general terms money laundering is the process of converting cash, or other property obtained by illegal, illegitimate or inhuman activity to legitimate and apparently legal one. One of the first formal definitions of money laundering to gain international recognition is that found in the United Nations' Convention against Illicit Traffic in Narcotic Drugs and Psychotropic Substances (commonly referred to as the 1988 Vienna Convention) and United Nations Convention Against Organised Crime [Palermo Convention (2000)].

Vienna convention in art 3(b) and (c) (i) states about it that the conversion or transfer of property, knowing that such property is derived from any offence or offences [related to drug trafficking] or from an act of participation in such offence or offences, for the purpose of concealing or disguising the illicit origin of the property or of assisting any person who is involved in the commission of such an offence or offences to evade the legal consequences of his actions. This convention also includes the concealment, or disguise the source, location, disposition, movement, rights with respect to, or ownership of property, knowing that such property is derived from an offence or offences from an act of participation in such an offence or offences; The acquisition, possession or use of property, knowing, at the time of receipt, that such property was derived from an offence or offences.

Likewise Palermo Convention (2000) art 6(i) states comprehensively regarding money laundering that;

"States Criminalisation of the laundering of proceeds of crime 1. Each State Party shall adopt, in accordance with fundamental principles of its domestic law, such legislative and other measures as may be necessary to establish as criminal offences, when committed intentionally: (a) (i) The conversion or transfer of property, knowing that such property is the proceeds of crime, for the purpose of concealing or disguising the illicit origin of the property or of helping any person who is involved in the commission of the predicate offence to evade the legal consequences of his or her action;"

The World Bank (2003) in the Global Fight Against Money Laundering and Terrorist Financing further describes that "Predicate offenses include virtually any serious crime generating proceeds, including kidnapping, theft, selling stolen goods, illegal arms trafficking, prostitution, corruption and fraud".

The above definitions are considered as a benchmark for rest of the states and international agencies in order to set their objectives and pursue their strategies pertaining to money laundering. Its significance is also global because 191 countries are members of UN. Global Programme against Money Laundering (GPML) is also directly operated by the UN. FATF being regulator of anti-money laundering endorses in Recommendation No.1, Scope 
of the criminal offence of money laundering that countries should criminalise money laundering on the basis of United Nations Convention against Illicit Traffic in Narcotic Drugs and Psychotropic Substances, 1988 (the Vienna Convention) and United Nations Convention against Transnational Organised Crime, 2000 (the Palermo Convention).

World Bank defines money laundering as:

It is the process by which the proceeds derived from a criminal activity (i.e., the predicate offense) are disguised in an effort to conceal their illicit origins and to legitimise their future use. The financing of terrorism is the financial support, in any form, of terrorism or those who encourage, plan or engage in terrorism. The two activities are linked because the techniques used to launder money are essentially the same as those employed to conceal the sources and uses of terrorist financing.

Over the times the domain and implications of money laundering made different states and international agencies to interpret and adopt different methods of controlling money laundering. Money laundering is not a single man act at a single moment rather it is a complex and multistage phenomena carried out in different stages.

\subsection{Stages of Money Laundering}

The process of cleaning dirty money is very complex. It involves devilish maneuvering so that dirty, illegal and illegitimate money give a clean and legal appearance. UNODC has identified three stages of money laundering that is placement, layering and integration as described below.

(a) Placement: During this initial stage illegitimately earned proceed is injected in the financial system. It reflects the movement of cash from its original source in different forms such as currency smuggling, bank complicity, currency exchanges securities brokers, blending of funds, and asset purchase.

(b) Layering: Layering is just like excessive soaping in the process of washing cycle. The main purpose of money layering is to make the laundering activity undetectable and complex. This is done through different methods such as cash conversion into monetary instruments, financial intermingling and frequent sale-purchase of precious assets and real estate.

(c) Integration: This final stage integrates illegal funds into financial setup. It enables the movement of previously laundered money into the economy mainly through the banking system in order to make such money apparently normal business earnings. The means include; property dealing, front companies, Shell companies, foreign bank complicity, and false or bogus import/export invoices.

It is evident from the process of money laundering that this is a more complex phenomenon having a set of characteristics which are highlighted in following paragraphs.

\subsection{Characteristics of Money Laundering}

Money laundering is conducted by the combination of different actors. These actors operate complex mechanism at different regions. They also have varieties of 
activities and available options. Following are some of the important characteristics (NBP):

(1) Money laundering is basically a group activity.

(2) Money laundering is practically a criminal activity and once began; normally there is no end to it.

(3) Money laundering recognises no boundaries. It has been internationalised.

(4) Money laundering activities are not one shot transaction; rather these involve a chain of transactions, and are undertaken at a large scale.

(5) Money laundering activities are carried out through a sophisticated and complex process.

Money laundering involves more than one person and the process is highly sophisticated and interdependent among agents and clients. Its transparency is difficult to achieve and implement, therefore, principal has to consider and handle this issue in more diversified and complex manner.

\section{NEGATIVE EXTERNALITIES OF MONEY LAUNDERING FOR FORMAL AGENTS}

Money laundering has multiple affects on different clients, agents and principal. It causes economic, social, political and administrative losses to agents and states. The principal and formal agents have to face negative implications on their economies due to money laundering. State's economies directly and indirectly suffer from this menace.

Different research scholars, professional experts and institutional studies inferred that money laundering and terrorist financing causes following problems.

- Destabilises economy of the country.

- Causes financial crisis.

- Give impetus to criminal activities.

- Increases corruption both at national and international level.

- Potential damage to reputation of financial institutions and markets

- Increases flight of capital.

- Discourages foreign investors.

- Possible destabilisation of financial markets and weaker financial institutions.

- Results in fragile and weak legitimate private sector.

- Promotes economic distortion.

- Causes revenue losses.

- Encourages tax evasion culture.

- Creates volatility in the equity market.

- Causes loose control over economic policy.

- Results in exchange and interest rates volatility.

- Undermines the process of democratisation in the developing countries.

- Promotes governmental inefficiency.

- Policy distortion occurs because of measurement error and misallocation of resources. 
- Erodes the credibility and legitimacy of state institutions.

- Promotes in human activities like human and drug trafficking.

- Provides opportunity to criminals to hijack the process of privatisation.

- Contaminates legal transactions.

- Potential reduction of foreign government assistance.

- Triggers annoyance of international community.

- International sanctions are imposed as FATF issues list of non-cooperative countries (NCCT).

- It causes variety of risks to national and international system.

- It undermines the very fabric of social set-up of the society.

Financial institutions are particularly affected by the process of money laundering. There is no denying the fact that financial institutions are engine of economic growth. When money launderer penetrates into these institutions they undermine their credibility and capacity. Vulnerable financial institutions intentionally or unintentionally damage the interests of all the stake holders. Money launderers cause reputational, operational, legal and concentration risks to these institutions. Basel Committee on Bank Supervision (2001) states about these risks:

Reputational Risk: "poses a major threat to banks, since the nature of their business requires maintaining the confidence of depositors, creditors and the general marketplace. Reputational risk is defined as the potential that adverse publicity regarding a bank's business practices and associations, whether accurate or not, will cause a loss of confidence in the integrity of the institution. Banks are especially vulnerable to reputational risk because they can so easily become a vehicle for or a victim of illegal activities perpetrated by their customers. They need to protect themselves by means of continuous vigilance through an effective KYC programme. Assets under management, or held on a fiduciary basis, can pose particular reputational dangers".

Operational Risk: It is defined as the risk of direct or indirect loss resulting from inadequate or failed internal processes, people and systems or from external events. Most operational risk in the KYC context relates to weaknesses in the implementation of banks programmes, ineffective control procedures and failure to practise due diligence. A public perception that a bank is not able to manage its operational risk effectively can disrupt or adversely affect the business of the bank. Legal Risk: It is the possibility that lawsuits, adverse judgements or contracts that turn out to be unenforceable can disrupt or adversely affect the operations or condition of a bank. Banks may become subject to lawsuits resulting from the failure to observe mandatory KYC standards or from the failure to practise due diligence. Consequently, banks can, for example, suffer fines, criminal liabilities and special penalties imposed by supervisors. Indeed, a court case involving a bank may have far greater cost implications for its business than just the legal costs. Banks will be unable to protect themselves effectively from such legal risks if they do not engage in due diligence in identifying their customers and understanding their business. 
Concentration Risk: It mostly applies on the assets side of the balance sheet. As a common practice, supervisors not only require banks to have information systems to identify credit concentrations but most also set prudential limits to restrict banks' exposures to single borrowers or groups of related borrowers. Without knowing precisely who the customers are, and their relationship with other customers, it will not be possible for a bank to measure its concentration risk. This is particularly relevant in the context of related counterparties and connected lending. On the liabilities side, concentration risk is closely associated with funding risk, particularly the risk of early and sudden withdrawal of funds by large depositors, with potentially damaging consequences for the bank's liquidity. Funding risk is more likely to be higher in the case of small banks and those that are less active in the wholesale markets than large banks. Analysing deposit concentrations requires banks to understand the characteristics of their depositors, including not only their identities but also the extent to which their actions may be linked with those of other depositors. It is essential that liabilities managers in small banks not only know but maintain a close relationship with large depositors, or they will run the risk of losing their funds at critical times.

On the other hand, anti-money laundering activities based on principal's policies may save a country from different crises and problems. Financial institutions provide needed funds for productive investment and pave the way for real economic development. Analysis of financial institutions failure/collapse and allied risks show that customer trust is very vital. Customer trust reflects level of social capital accumulated by financial institutions, that stock of social capital also contributes to the investment and accumulation of social capital of respective institutions, this has been reconciled with the works of Putnam (1993, 1998, 2000), Temple (2001) and Woolcock (1998, 2001). Similarly, social capital adjusts the level of risk to depositors and investors from expected institutional fraud and corruption.

The real economic growth is badly affected by the predicate offences of money laundering. As criminal activities like, smuggling, terrorism, corruption, drug trafficking etc. are not only cause and effects of crimes but it also multiplies negative socioeconomic culture. In such culture resources are used and diverted according to the whims of different mafia. They divert resources to non productive ventures and most of the time move in conflict of official priorities. The same is reconciled by Bartlett (2002) who points out that money laundering carried out through the channels other than financial institutions includes more "sterile" investments such as real estate, art, antiques, jewelry, and luxury automobiles, or investments of the type that gives lower marginal productivity in an economy. The suboptimal allocations of resource give lower level of economic growth as pointed by different studies for example [Baro and Sala-i-Martin (2004), Baro (1997) and Barro (2001)].

This is an age of globalisation. Every country has to interact with other state to promote its political and economic interests. Reuter and Truman (2004, p. 171) are of the view that "with the increased globalisation of the financial system, money laundering has evolved into an activity affecting societies and financial systems everywhere in the world." Money laundering activities cause international disrepute as Non-cooperative countries List (NCCT) and "Name and Shame List" not only cause reputational loss but 
also economic loss. It also discourages foreign investment and foreign trade. Thus apprehensions, lack of trust, disrepute and isolation effect foreign investment, exports and flight of capital. The states know that it's a cyclic game so any strategy in the initial period will also determine a reaction and subsequent counter reaction of principal, which is not in long run interests of a state (formal agent).

In view of above expected costs and returns formal agents may extend their cooperative strategy to the principal's objectives and strategy of curbing money laundering.

\section{LOSSES TO PRINCIPAL}

Money laundering causes global loss. It impairs the process of globalisation. Financial crises in the world result from criminal activities. Financial transparency is also badly affected by it. Terrorist activities hinder global peace and stability which adversely affects the performance of the Principal. Global trade is severely affected by the money laundering activities. So global financial regulators feel money laundering a real threat to their global interests. Terrorists' attacks of September 11, 2001, prompted the world community to make efforts to combat money laundering and the financing of terrorism. Now a-days Money laundering is considered as main source of financing terrorism, a threat to global security, financial stability, transparency, and efficiency of financial market. Money laundering facilitates the criminals and terrorists to operate, as it results into expansion of their financial gains which they use for criminal activities. Money laundering nurtures illegal activities such as corruption, drug trafficking, arms trafficking, smuggling at local and across the boarder. This hampers institutional stability, economic growth, and societal order at local and international level. Especially in the developed world it is mainly considered as an important cause of promotion of potential threats of terrorism to their citizens. Money laundering has been turning a matter of concern not only to state rather a test of capability of international financial regime that is expected by citizens and states in the developed world. So the credibility of principal to protect interests of international community is under threat with the increase in money laundering. Likewise, financial markets' failure also erodes credibility and legitimacy of principal.. Therefore the principal has to minimise its losses by adopting a global strategy to control money laundering.

\section{STRATEGY OF THE PRINCIPAL}

Principal i.e. International financial regime counts present value of her returns specially from developed economies which are their principal as Provan and Milward (1983) view that "in agency-theory terms", these are the principals whose role is to fund and/or monitor the activities of their agents (network agencies), who provide services to their clients. The developed economies want that the money transaction should be carried out through the means not clashing with their interests so the transaction of money through money laundering is unmonitorable and suspected to serve the interests of the people adversely affecting their interests. As the international financial regime acts as principal to different states, institutions, organisations and banking institutions for implementation and monitoring of laws pertaining to money transactions simultaneously it acts as an agent to the developed world to extend goods and services to pursue their 
objectives of curbing money laundering. Most of the contributions towards development of international financial regime at initial stage followed by ongoing expansion is made by the developed economies. So they get returns from the already made investment linked with future expected investment. Returns from international financial regime are in the form of services provided to maximise the transparency, stability and monitoring of money transaction made through different agents through different channels. The main objective is to minimise the money transaction through illegal channels which is suspected to be linked with terrorist activities against the developed world.

Principal pursues her objectives in order to get returns by controlling money laundering through governance of available choices in the network and system of money transaction. Laws, procedures and regulations are framed and states, financial institutions, organisations and banking institutions are obliged to follow and observe these laws and rules pertaining to transaction of money. So the states, financial institutions and organisations act as agent of the principal to implement their framed rules in order to achieve already set objectives. As the principal prefers to pursue anti money laundering measures through her agents so they make rules and procedures and strategy to get maximum of transactions of money in line with their framed rules/procedures and channels in turn leading to achieve their objectives. These agents specifically states also act at the same time as principal in local system of governance of money transaction, this dual role is in line with agency theory of Fama and Jensen (1983).

As the states are assumed as rational agents so they compare present value of marginal cost of not serving the interests of the principal and present value of returns from extending their services in governance of money transaction in line with the objectives of the principal. The principal makes the laws for making monitoring more easy and transparent so that the role of agents in this regards may be more contributing in the effective governance of money transaction specially in curbing money laundering through different measures.

\section{MONEY LAUNDERING COUNTER-MEASURES}

Money laundering being a potential threat to different stakeholders of financial systems has facilitated many of the formal agents and principal to make joint effort to counter this menace. Principal has extended its mandate with target based establishment of organisations and extension of objectives for anti-money laundering. Different organisations and institutions involved in the process of anti money laundering include Financial Action Task Force (FATF), the Council of Europe, the Commonwealth Secretariat, the International Monetary Fund (IMF), the Inter-American Drug Abuse Control Commission (CICAD), Interpol, the International Organisation of Securities Commissions (IOSCO), the Offshore Group of Banking Supervisors (OGBS), the United Nations International Drug Control Programme (UNDCP), the World Bank and the World Customs Organisation (WCO).

Similarly the principal is involving different formal agents (states and international financial organisations) through contracts to extend their cooperation against money laundering. Different types of agreements have been carried out among agents and principal in the legal, financial, regulatory and. law enforcement areas to take action against money launderers. 
Legally, money laundering is being recognised as criminal act at national and international level. UN, FATF, IMF and World Bank took such initiatives which bind states to take legal measures. With these steps now money laundering has been recognised as a crime and world community i.e. principal and formal agents have to deal with it accordingly. A major strength is drawn from the initiatives of UN. One of the first formal legal dimensions of money laundering to gain international recognition is that found in the United Nations' Convention against Illicit Traffic in Narcotic Drugs and Psychotropic Substances (commonly referred to as the 1988 Vienna Convention) and United Nations Convention Against Organised Crime (Palermo Convention 2000). The 1988 Vienna Convention deliberated to take joint action against laundering of drug proceeds, while, United Nations Convention Against Organised Crime (Palermo Convention 2000, covers comprehensive predicate offences. This convention also called on states (agents) to outlaw the most common offenses, including ML, and for closer international cooperation in extradition, mutual legal assistance, transfer of proceedings, and joint investigations. The United Nations Office on Drugs and Crime's Global Programme Against Money Laundering has developed model laws and delivers technical assistance (TA) to UN member states to assist them in the implementation of the UN conventions relevant to AML and CFT.

The principal has taken several anti money laundering measures pertaining to reporting of transactions involving funds suspected of being proceeds of drug trafficking, terrorism, corruption etc, reporting of international financial transfers, regulation of over the counter exchange dealing (bureaux de change), regulations for financial and non financial institutions. Customer identification criteria in financial institutions have become almost global. Consequently, these legal measures have been further adopted by many of states in drafting their local laws.

In addition legal framework has been devised in 1988 Vienna Convention, Palermo Convention 2000, FATF Recommendations, and the Council of Europe's 1990 Convention on Laundering, Search Seizure, and Confiscation of the Proceeds of Crime (the Strasbourg Convention). Comprehensive measures for the identification, tracing and seising of proceeds of crimes is being shared. Legislative measures enable competent authorities to confiscate laundered monies and property acquired from illicit sources. It also enables states to have international cooperation for combating the money laundering and terrorist financing.

International Financial Regime has also taken financial and regulatory measures to counter money laundering. Financial Action Task Force, Basel Committee on Banking Supervision along with IMF and World Bank took measures to eliminate anonymous and fictitious accounts in financial institutions. These institutions are required to maintain records of the identity of their clients (commonly known as the 'know your customer' policy). Financial institutions have to develop programme to guard against money laundering including internal controls and employee training. Special attention has to be paid to complex, unusual and large transactions. Unusual transactions are supposed to be reported to competent authorities. All the countries have to consider implementing measures to detect or monitor cash at national borders.

Principal also took measures for the enforcement of law through increased international cooperation in training, technology transfer, information sharing and other 
joint controlling measures. Countries also cooperate and assist in investigations and prosecutions. Consequently, international network of bilateral and multilateral assistance for the methods and means by which one country might assist another in investigations, prosecutions and confiscation is established. This network facilitates and protects interests of its integrating partners and clients. FATF styled Regional bodies also play important role in this regard e.g Asia/Pacific Group on Money Laundering was established to provide a focus for co-operative anti-money laundering efforts in the region; with shared experience and through exchange of information and joint efforts to handle and combat such criminal activities. Similarly Caribbean Financial Action Task Force comprising states in the Caribbean and northern South America have adopted the 40 Recommendations of FATF alongwith some additional region-specific recommendations and measures. In addition the principal plays its strategy through it's specialised agencies and group of agents at different occasions in different areas to control money laundering.

\section{ROLE OF THE BRETTON WOODS INSTITUTIONS}

IMF and the World Bank have assumed a major role as a principal in supporting the efforts of FATF, UN, IOSCO and IAIS etc to combat money laundering and terrorist financing.

\section{International Monetary Fund}

IMF has intensified its efforts against money laundering to assess and strengthen international financial systems through multiple efforts and facilitated in part by the development of the Financial Sector Assessment Programme (FSAP) and its Offshore Centre Assessment Programme. Owing to the intensity of this problem in 2001, the Board of IMF discussed the issue of money laundering and the ways in which IMF can contribute to related international efforts to protect the integrity of the international financial system. It has also been realised by the IMF that elimination of money laundering is in the interest of international community. Providing support to international efforts to combat money laundering was considered to be one way in which this objective could be achieved. It was decided that IMF should intensify its focus on anti-money laundering issues, establish a closer working relationship with the major international anti-money laundering organisations and groups. Besides, technical assistance IMF also included anti-money laundering measures in its operational activities.

\section{World Bank}

World Bank took diversified measure to counter money laundering. The World Bank has expanded ambit of its programmes in the areas of anticorruption, governance, and public financial management; and assisted countries in carrying out financial sector reforms focusing on legal, regulatory, and supervisory issues. Its financial sector lending and technical assistance activities rapidly increased through programmes to strengthen legal, regulatory, supervisory, judicial reforms, institutional reforms, corporate governance, accounting and auditing, and market transparency. These reforms have direct 
relevance with anti money laundering measures. It provides technical assistance to member countries to strengthen their Anti-Money Laundering programmes. It also initiated various measures to ensure that its anti- money laundering assistance is used for the intended purposes and is not subjected to financial abuse.In this regard Efforts are made for knowledge sharing, awareness raising, and information exchange amongst the member countries. Global Dialogue Series and Anti-money laundering conferences are held in different regions of the world.

\section{Joint International Monetary Fund and World Bank Initiatives}

In addition to their individual efforts these international agencies carried out joint programmes to curb money laudering. IMF, and World Bank, have introduced the FSAP providing for Joint IMF-World Bank assessments of the financial sectors of their common member countries. This programme was designed to identify strengths, risks, and vulnerabilities in national financial systems and help promote the soundness of such systems. The FSAP assesses, members' adherence to internationally accepted financial standards, codes, and best practices. These institutions also take into consideration efforts of Basel Committee, IOSCO and IAIS. These international financial regulators have extended ambit of their activities to observance of standards and codes relating to financial sector standards along with the banking, insurance, and securities sectors.

\section{Asian Development Bank and Anti-money Laundering Activities}

Asian Development Bank has been assisting to combat money laundering by incorporating relevant elements in existing policies and strategies to facilitate poverty reduction, promote good governance and anticorruption, and strengthen national financial systems. These efforts have directly and indirectly contributed to reduction of money laundering and terrorist financing.

The strategy adopted by the principal only covers formal agents such as states, financial institutions and banking institutions in order to combat money laundering. The informal agents operating and participating in transaction of money laundering are given little weight rather only coercive measures are proposed to bar them from such activities.. This strategy of the principal is analysed in the following model whether it's a viable and rational to exclude these agents or otherwise?

\section{THE MODEL}

All the integrating partners of the financial system such as principal, agent and client, make their decisions rationally while taking into account the available choices and their preferences. They count present value of their costs of making specific decisions regarding their role in system of money transaction and present value of returns from adopting specific role. Informal agents operating and participating in transaction of money laundering also decide their participation in money laundering while, taking into account present value of their costs and returns.

The cost and returns to different agents, principal and clients can be modeled along the lines of Becker (1993) who made calculation of present value of cost of investment in human capital and present value of returns from investment in human capital. We 
modeled the cost of adopting strategy by clients and agents whether to cooperate with the principal while, making decisions on the channels to be followed for transaction of money. As the principal wants the governance of money transactions based on the principle of transparency and monitorability, thereby, persuading agents and clients to adopt legal channel and cooperate in anti money laundering efforts.. There are $i$ periods and returns $Y$ from cooperative strategy with the principal. It is assumed that there is a stream of real net earnings $Y_{0}$ during period one followed by later periods up to $Y_{n}$. The term real earnings are defined as the sum of monetary earnings and the monetary equivalent of psychic earnings as by Becker (1993) the present value of net earning stream $Y$ is

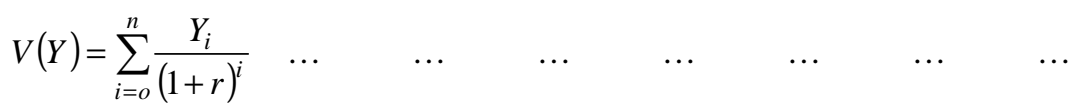

Whereas $r$ is market discount rate assumed for simplicity the same in each period. Assume that there is $X$ non-cooperative strategy of the clients and agents with the principal then net earning stream will be from $X_{0}$, to $X_{n}$ so the present value of gain from of the strategy $\mathrm{Y}$ can be found as in Equation (2)

$$
d=V(Y)-V(X)=\sum_{i=0}^{n} \frac{y_{i}-X_{i}}{(1+r)^{i+1}} \quad \ldots \quad \ldots \quad \ldots \quad \ldots \quad \ldots \quad \ldots
$$

This equation can be retransformed for more transparent cost finding so we assume that by adopting the strategy of cooperation the agent and client make some investment by paying additional taxes and charges for transaction of money through the channel recommended by the principal. Contrarily no additional investment is required on transaction of money through illegal channel and money laundering, thereby, adoption of strategy $X$. The cost of adoption of cooperative strategy $Y$ relative to non-cooperative strategy $X$ is the difference between their net earnings in the initial period and the total returns would be the present value of the differences between net earnings in later periods. As the agents have to get returns in monetary and other forms in later periods by cooperation with the principal but the clients may not have the same type and quantum of returns. So by adopting cooperative strategy clients (for example worker supply labour abroad) may get lesser returns as their stay abroad is shorter and their linked non monetary returns are very few if not zero. Their optimal strategy may be the non cooperative one, if;

$$
C=X_{\circ}-Y_{\circ}, k_{i}=Y_{i}-X_{i}, \text { as } i=1 \ldots \ldots \ldots n
$$

And $R$ is total returns then the gain from $Y$ is given as

$$
d=\sum_{i=1}^{n} \frac{k_{i_{i}}}{(1+r)^{i}}-C=R-C \quad \ldots \quad \ldots \quad \ldots \quad \ldots \quad \ldots \quad \ldots \quad \ldots
$$

The value of $d$ is very much a determining variable in decision making process by the rational agent, and clients. The clients and agents want to maximise $d$ which can be maximised in two ways either to maximise $R$ or minimise $C$. As rules of the game for 
governance of money transaction are set by the principal along with the control over the process of rule making. With the control of rules by principal the clients have the option either to follow the rules by cooperative strategy and accept lesser $d_{c}$ or adopt a strategy of non cooperation with the principal and agents and make money transaction through the channel enabling him get higher value of $d_{n}$.

Optimal level of $d_{c}=d_{n}$ and $d_{c}-d_{n}=0$ and this condition leads to stability of the system of money transaction. The principal will have to bring both the $d$ closer to each other and make $d_{c}$ more acceptable for the clients and agents. The more risk avers are the number of clients in and agents in the system of financial and banking sectors more will be the probability that non cooperative $X$ strategy is adopted and the principal has to increase value of $d_{c}$ in order to attract more number of clients and agents with strategy $Y$. The value of $d_{c}$ and $d_{n}$ may be found through monetary and non monetary variables.

We may understand the nature of relationship existing between cost and returns with the application of internal rate of return method (IRR). In this case we may assume that the discount rate $r$ which equates the present value of costs to present value of returns is given below;

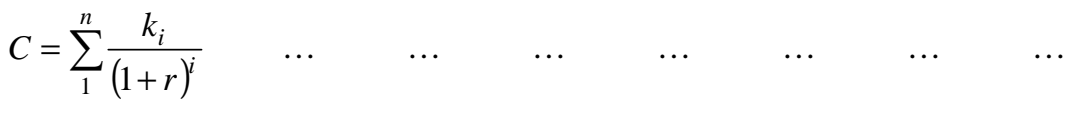

$$
\begin{aligned}
& \sum_{i=0}^{n} \frac{Y_{i}}{(1+r)^{i+1}}-\sum_{i=0}^{n} \frac{X_{i}}{(1+r)^{i+1}}=d=0 \quad \ldots \quad \ldots \quad \ldots \quad \ldots \quad \ldots
\end{aligned}
$$

The formal and informal agents decide their strategy in view of their expected stream of costs and returns from a particular strategy. There is a pay off matrix for agents and principal along with relative expected gains to each player of the game which is given below;

Principal-Agent's Pay-off Matrix

\begin{tabular}{lcc}
\hline \multirow{2}{*}{ Principal } & \multicolumn{2}{c}{ Agent } \\
\cline { 2 - 3 } Incentive & Co-operative & Non co-operative \\
No Incentive & $(\mathrm{a} 1, \mathrm{~b} 1)$ & $(\mathrm{a} 2, \mathrm{~b} 2)$ \\
& $(\mathrm{a} 3, \mathrm{~b} 3)$ & $(\mathrm{a} 4, \mathrm{~b} 4)$ \\
\hline
\end{tabular}

The main objective here is to maximise the social welfare i.e.

Maxi $x_{i}=a_{i}+b_{i}$ subject to constraint $\Delta a_{i} \geq b_{i}$ where $i=1,2,3,4$

Here $a_{i}$ and $b_{i}$ are respectively the gains of principal and agent from different choices of outcomes. With the assumption that both the principal and the agent are working in their own interest, bargaining take place in such a way that each of them try to maximise his gain. The principal has some power to control the behaviour of agent by offering incentives in the case of not cheating and penalties otherwise

The game is started from the case where agent activity is harming the principal gain in such a way that social welfare is also affected negatively i.e. (a4, b4). Or in other words we can say that gain of agent from his behaviour is less than loss of principal. 
The best option from the agent point of view is (a2, b2), where he gets benefit from incentives offered by principal as well as by cheating. While, from the principal point of view the best option is $(a 3, b 3)$, where he gains without incurring any cost, but there is no free lunch hence both $(\mathrm{a} 2, \mathrm{~b} 2)$ and $(\mathrm{a} 3, \mathrm{~b} 3)$ are not optimal solutions. If agent opts to cheat he may face penalty if caught, and if principal does not offer incentives he may lose due to cheating by agent. The only solution left is (a1, b1) with the conditions $a 1 \geq a 4$ and $b 1 \geq b 3$. This implies that solution lies in between the two extremes those are (a2, b2) and (a3, b3).

This analysis can be extended to any number of agents and principals as well as clients by additional assumptions.

\section{CONCLUSION}

In view of above discussions it is concluded that the existing strategy of the principal is sub optimal and quasi sustainable as two of the integrating partners of this system of money transaction i.e. principal and agents may cooperate and work jointly to make laws, rules and procedures and attempt to implement these laws so as to make money transactions more transparent and more monitorable. The desired objective of the principal is to minimise, detect and deter money laundering. The optimal strategy of the agents is to reduce this crime and enhance public welfare along with other attainment of national interests. Clients take into account cost and benefit analysis and act accordingly. To minimise money laundering the present value of marginal cost of non-cooperation seems optimal as compared to the present value of returns from transaction of money through money laundering in the existing set of rules and laws. Therefore there is need to have more incentives for the clients.Thus compatability and convergence of interest can bring desired results.

\section{POLICY RECOMMENDATIONS}

Therefore, the principal (International financial regime and developed economies) may have induced more incentives to increase present value of returns from cooperation with the principal and agents. The principal should also reduce present value of marginal cost to the clients which he has to bear by cooperating with the principal and agents. The international financial regimes may make more conducive laws and procedures that enable clients to get money transaction in shorter time and with lesser cost as long as the difference in the cost and benefits increases the non-cooperation increases. Similarly, additional charges and taxes and other type of additional costs increase the noncooperation, therefore, the developed world through subsidy or other alternative laws and procedures may reduce the present value of marginal cost of cooperation.

\section{REFERENCES}

Barro, R. J. (2000) Education and Economic Growth. Harvard University. (Working Paper.)

Barro, Robert J. (1991) Economic Growth in a Cross Section of Countries. Quarterly Journal of Economic 106, 407-443.

Barro, Robert J. (1996) Determinants of Economic Growth: A Cross-country Empirical Study. National Bureau of Economic Research. (Working Paper, 5698, pp. 71.) 
Barro, Robert J. (1999a) Inequality, Growth, and Investment. National Bureau of Economic Research. (Working Paper: 7038, pp. 71.)

Brent L. Bartlett (2002) The Negative Effects of Money Laundering on Economic Development. Asian Development Bank.

Cuéllar Mariano-Florentino (2003) The Tenuous Relationship between the Fight against Money Laundering and the Disruption of Criminal Finance. The Journal of Criminal Law and Criminology (1973) 93:2/3.

Fama, Eugene F. and Michael C. Jensen (1983) Separation of Ownership and Control. Journal of Law and Economics 26:2, 301-15.

FATF (2004) Report on Money laundering Typologies 2003-2004. Paris.

FATF (2006) Financial Action Task Force Annual Report 2005-2006. Paris.

Financial Action Task Force on Money Laundering the Forty Recommendations. Accessed in June 2006 (http://www.fatf_gafi_.org/document).

Global Programme Against Money laundering (2007) <http://www.unodc.org/unodc/en/ money_laundering.html>

International Monetary Fund (IMF) (1998) Money Laundering: the Importance of International Countermeasures, Address by Michel Camdessus, then Managing Director of the International Monetary Fund at the Plenary Meeting of the Financial Action Task Force on Money Laundering in Paris, February 10 <http://www.imf.org/external/np/speeches/1998/021098.htm>. Accessed on 6/5/07. Washington, DC.

Kohler, Miles, and David A. Lake (2003) Governance in a Global Economy. Princeton: Princeton University Press.

Levi, Michael (2002) Money Laundering and Its Regulation. Annals of the American Academy 582, p. 186.

Malik, Munir A. (2003) Bankers Guide on Anti-Money Laundering-Initiatives and Legislation. Lahore: McKay Corporate Institute, 13-14.

Mulligan, C. B. and X. Sala-i-Martin (1995) A Labour-Income Based Measure of the Value of Human Capital: An Application to the States of the United States.

National Bank of Pakistan (NBP) (n.d.) Policy Manual Anti-Money laundering AntiTerrorist Financing.

Pakistan, Government of (1997) Control of Narcotics Substance Act 1997.

Pakistan, Government of (1999) National Accountability Ordinance. Islamabad.

Pilbeam, Keith (1998) Finance and Financial Markets. London: Macmillan Press.

Provan, Keith G. and Milward H. Brinton (2001) Do Networks Really Work? A Framework for Evaluating Public-Sector Organisational Networks. Public Administration Review 61:4, 414-423.

Quirk, Peter J. (1997) Money Laundering: Muddying the Macroeconomy. Finance and Development 34:1.

Schneider, Friedrich and Dominik H. Enste (2000) Shadow Economies: Size, Causes, and Consequences. Journal of Economic Literature 38:1, p. 77.

State Bank of Pakistan (SBP) Annual Report FY 05.

Tanzi, Vito (1999) Uses and Abuses of Estimates of the Underground Economy. The Economic Journal 109:456, p. 338. 
United Nations (1988) United Nations Convention Against Illicit Traffic in Narcotic Drugs and Psychotropic Substances (Vienna Convention). United Nations.

US Interagency Efforts to Combat Terrorist Financing-Bureau of Economic and Business Affairs (2003)

Wayne E. Anthony (2005) Money Laundering and Terrorist Financing in the Middle East and South Asia. http://www.state.gov/e/eeb/rls/rm/2005/49564.htm

World Bank (2003) The World Bank in the Global Fight Against Money Laundering and Terrorist Financing. USA. 